$\underline{\text { Article }}$

\title{
Global Citizenship and Business Education, Part 2: The Role of Business Schools
}

\author{
José R. de la Torre', Corinne B. Young ${ }^{2}$ \\ 1 University of Bologna Business School, Italy, and Florida International University (Emeritus), USA, ${ }^{2}$ Franklin University Switzerland, Switzerland \\ Keywords: teaching business responsibility, business schools and csr, corporate social responsibility, global citizenship
}

\section{AIB Insights}

Vol. 20, Issue 1, 2020

\begin{abstract}
Over the last decade we have seen increased demands for full stakeholder models in global decision-making and greater emphasis by accrediting agencies that business schools show their commitment to societal ends. The COVID-19 pandemic has brought these issues to the fore. We trace early developments in how business schools dealt with these demands and analyze the data from the Aspen Institute's survey of business schools' commitment to global citizenship programs. We then review more recent efforts and report on several institutional and collaborative efforts to promote a global citizenship agenda among business schools and their curricula.
\end{abstract}

\section{INTRODUCTION}

Our first article in this issue of AIB Insights traced the historical origins of the concept of global citizenship and enumerated the skills, characteristics and values that global citizens must possess in order to fulfill their resulting obligations. We argued that when economic, social and technological issues transcend boundaries - both morally and physically - only responsible global citizens can ensure that business decisions are consistent with the sustainability of our planet and the wellbeing of its inhabitants. Today we examine what business schools are doing to train such executives and identify gaps where greater effort may be needed.

Business schools have been "internationalizing" their curricula for almost half a century. Although considerable progress has been made and most accreditation standards have been met, any commitment to educating business students to become global citizens is still in its infancy. The 2000 Millennium Declaration launched a new commitment by nations to a global partnership in support of economic and social development. Upgraded and expanded in the UN's 2030 Agenda for Sustainable Development, ${ }^{1}$ the urgency of this task was echoed in an increased demand for full stakeholder models in global decision-making and a greater emphasis by accrediting agencies that business schools show how they contribute to society as a whole. The current COVID-19 pandemic has brought these issues to the fore. One of the UN's Sustainable Development Goals (SDG \#4) specifies that all students should acquire the skills needed to promote sustainable development, and global citizenship education is included as one of the essential elements to achieve this goal. ${ }^{2}$ But the world cannot afford to wait until future generations become educated in global citizenship; business schools need to act now to ensure that the next cohort of decision makers possess these essential skills and values.

\section{EARLY EFFORTS TO PROMOTE THE TEACHING OF GLOBAL CITIZENSHIP}

Change among business schools began after numerous critics argued that many of the soft leadership skills essential for a successful career in management had been shortchanged in favor of quantitative techniques and analytical model building (Bennis \& O’Toole, 2005; Ghoshal, 2005; Mintzberg, 2004; Pfeffer \& Fong, 2002). Simultaneously, the AACSB began a campaign to emphasize the roles and responsibilities of business as a global force, particularly in terms related to societal responsibility and sustainability (AACSB, 2006; Bisoux, 2008). In 2007, a number of business schools and accrediting agencies proposed a set of standards consistent with the goals of the UN Global Compact, first adopted in 2005. These "Principles for Responsible Management Education" (PRME) were intended to raise the profile of sustainability in business schools around the world, and to equip business students with the understanding and ability to deliver change. "Faculty at PRME schools are the pioneers of responsible management education. Their thought leadership inspires transformation. Their teaching enables it.” (United Nations, 2017). Today, there are over 800 signatories in nearly 90 countries organized into 14 regional chapters.

Nearly a decade ago, the Aspen Institute conducted two granular surveys among nearly 150 business school programs around the world in terms of their commitment to many of the principles of global citizenship discussed earlier (The Aspen Institute, 2009, 2011). ${ }^{3}$ We analyzed the data in these studies and classified all self-reported activities into a matrix that included four "social" target areas asso-

1 https://sustainabledevelopment.un.org/post2015/transformingourworld

2 Perhaps the earliest educational attempts to promote global citizenship can be traced to the National Model United Nations (NMUN) programs instituted in the 1950s in many countries. These programs are still widely taught at high school and university levels and have recently incorporated the 2030 SDG Agenda into the curriculum. 
ciated with global citizenship and eight types of academic activities. These were:

\section{TARGET AREAS:}

- Sustainability: safeguarding our environment, climate change, the sustainable use of resources.

- Corporate responsibility \& ethical behavior: transparency, social responsibility, ethical behavior.

- Global \& community development: contributions to the broader communities and stakeholders of firms and schools, volunteering in local non-profit organizations, global NGOs, etc.

- Social entrepreneurship: a focus on the development of social entrepreneurs at home or abroad.

\section{ACTIVITIES:}

- Focused programs: those dealing exclusively or primarily with one of the target areas.

- Concentrations: a series of specialized courses in a given target area.

- Joint degrees: an MBA plus a specialized master's degree in a field related to a target area.

- Core or Elective courses: a categorization by target area of all courses described in the reports.

- Institutes or Centers: entities focused on research, education or outreach in one of the target areas.

- Conferences: disseminating information on issues within a target area.

- Experiential activities: formal opportunities for students to work in organizations directly involved in one of the target areas through internships, summer work programs, etc.

- Student Clubs: student-led organizations whose focus is related to a target area.

Table 1 summarizes our findings. Corporate responsibility and ethics garnered the most attention in terms of courses, centers and conferences, and scored well in terms of student clubs and academic concentrations. Programs focused on sustainability ran a close second, but the emphasis here was more in terms of concentrations and joint degrees, often with schools of engineering and science, and included the only two focused programs in the sample at the time (Bainbridge Graduate Institute and Presidio School of Management), which have since merged. Surprisingly, academic programs focused on global and community development were scarce in spite of student interest in experiential programs and student clubs contributing to local and global communities. Finally, the field of social entrepreneurship, perhaps the one area closest to the core of the standard business curriculum, appeared severely underdeveloped among business school programs.

\section{WHAT NEXT?}

The number of centers and institutes for global citizenship and sustainability are growing rapidly, as are independent degree programs not associated with traditional university departments. The Global Social and Sustainable Enterprise Program at Colorado State University's College of Business ${ }^{4}$ and the Erb Institute for Global Sustainable Enterprise at the University of Michigan ${ }^{5}$ were early leaders in introducing sustainability to the graduate business curriculum. The focus of the stand-alone Presidio Graduate School in California referenced above is its Sustainable MBA program. ${ }^{6}$ These schools' mission is to develop leaders who build enterprises that are financially successful, socially responsible and environmentally sustainable. In other words, they aim to develop individuals who will lead their organizations to be good global citizens.

We have also seen considerable efforts to promote social entrepreneurship by organizations such as Ashoka ${ }^{7}$ as well as a "shift toward extensive research and teaching on social entrepreneurship" (The Aspen Institute, 2020). Furthermore, a recent emphasis on corporate social intrapreneurship promises to yield significant results (McGaw \& Malinsky, 2020). And yet, program innovation in teaching global citizenship is not as widespread and transformational as it should be. There are several familiar reasons for this. Introducing "horizontal" issues (such as internationalization, entrepreneurship or ethics, to name a few) to the curriculum is difficult politically and expensive. Strong discipline-based departments often resist it as being contrary to their standards of rigor and academic excellence. And current faculty members may not have the commitment or the knowledge to develop learning experiences that will allow students to accept that they have the agency to make changes (Janjuha-Jivraj, 2019).

Business schools have a crucial and urgent role to play today in educating global citizens. We must become conscious of the impact of our actions have in shaping the world view of current and future business leaders whose companies often have more wealth and influence than the nations whose markets they serve. If only current leaders in corporations, governments, and international organizations had received an education grounded in responsible and moral global citizenship, would we have experienced the devastation of the 2008 global financial crisis? Would the COVID-19 pandemic have wreaked so much havoc? Two faculty members at Monash University argue that "Leadership during this crisis is going to require humanistic responses and approaches... [involving] integrated thinking, holistic management, and the conscious development of an ecological mindset to actively incorporate societal and environmental factors into corporate decision-making” (The Aspen Institute, 2020).

The new economy of the 21st century demands that global citizens work together to create a sustainable world

\footnotetext{
3 It is extremely unfortunate that these surveys were discontinued after 2011.

4 www.biz.colostate.edu/ms/gsse/

5 www.erb.umich.edu/Education/Masters/MBA-MS

6 https://www.presidio.edu

7 Ashoka is a leading global organization that promotes social entrepreneurs and cultivates a community of change leaders where everyone can be a changemaker. Through their "Ashoka U” program they have engaged over 150 universities and business schools to promote inter-disciplinary, entrepreneurial and results-oriented skills among college students. See https://ashokau.org for more details.
} 
in which all people and Mother Earth are valued. What a noble goal for business schools to value. "Global Citizenship learning provides the 'conceptual glue' linking sustainability, social responsibility, and ethical practice in Business Schools” (Lilley, Barker, \& Harris, 2014). A clear vision and commitment to the implementation of a multidisciplinary and integrated business education strategy requires revolutionary leadership and flexible organizations, not often found in traditional universities. If we are not active global citizens, questioning the social, political, and economic institutions in our lives, how can we create and deliver a curriculum that gives students the knowledge and skills they need to become global citizens?

\section{SOME RECENT INITIATIVES}

Tricia Bisoux (2019) recently highlighted two experiential learning initiatives that demonstrate the power that students have to change the world for the better. The University of San Diego sponsors the Fowler Global Social Innovation Challenge where student teams at universities worldwide are invited "to imagine new business ideas that generate profits while solving social problems." The Russian Academy of National Economy and Public Administration (RANEPA) sponsors a program called Summer Campus bringing students together for personal and professional growth, developing practical approaches to the realities of modern economic and social space.

Often small, liberal arts universities have greater capacity to be flexible and adaptable. In 2019, Franklin University Switzerland faculty reimagined their MS International Management program for the "new" economy. ${ }^{8}$ Learning experiences are grounded in the knowledge, mindsets and skills required to become a responsible global citizen. Donut Economics (Raworth, 2017) and the Golden Rule (Polman \& Vasconcellos-Sharpe, 2017) are two key frameworks that MSIM students explore in their learning. A concentration in "responsible management and climate action" in partnership with the UN Agency for Training and Research in Geneva allows students to work for six weeks with a UN Agency project team in their area of concentration. Another example is the University of Vermont's Sustainable Innovation MBA, where they have "reinvented business education and the MBA degree to address directly the core challenges we face-environment, ethics, poverty and inequality-through the lens of enterprise and entrepreneurship." "

The Global Citizenship Education Working Group, a collegium of 90 organizations that includes several universities and experts at the Brookings Institution and several UN agencies, surveyed 50 international programs and initiatives focused on global citizenship education for youths aged 15-24. One key finding pertained to evidence of taking action and not just thinking about how to achieve SDGs, with action-focused tools most prevalent within certification efforts. Another gap concerned insufficient efforts to understand two key elements of our globalized world: diver- sity and interconnectedness (Brookings Institution, 2017). Once again, these shortcomings highlight the need for experienced educators who have firsthand experience in global citizenship development as well as the understanding of how to convey this knowledge to students.

\section{CONCLUSIONS}

In recent years, several scholars have argued that adding a social dimension to a company's value proposition offers a new frontier in competitive positioning and that profitability can be enhanced when companies are actively engaged in the resolution of global issues (Awaysheh, Heron, Perry, \& Wilson, 2020; Porter \& Kramer, 2006). ${ }^{10}$ Historically, business educators have based much of the curriculum on the concept of creating and sustaining competitive advantage. To the extent that a company's value proposition can be enhanced through responsible citizenship, we would be remiss to not include social issues and responsibility in the management curriculum.

An increasingly powerful force comes from student demand. Robert I. Joss, former dean of the Stanford Business School, highlights the fact that more prospective students are looking for MBA programs that will teach them to "dissect tough management issues and develop socially innovative solutions in areas such as environmental sustainability, bioethics, the alleviation of global poverty, health care and education.” Angel Cabrera, president of George Mason University, also sees a change of mindset on the part of business students, "Students do not want to have to choose between having a great career and making a difference in the world: they want to do both" (Hulstrand, 2007). In a recent survey of over 1,700 business students from 40 countries, researchers from Macquarie Graduate School of Management (Haski-Leventhal \& Pournader, 2017) concluded that over $90 \%$ of them would be willing to sacrifice some percentage of their salary (including $14 \%$ willing to give up more than $40 \%$ of future income) in order to work for a socially responsible employer.

The demand for business school graduates to be "more cosmopolitan" in their moral, political, cultural, and economic perspectives, has begun in earnest. In 2007, IBM invested $\$ 60$ million in the creation of the Global Citizen's Portfolio for its employees. It also developed its own global citizenship training program called The Corporate Service Corps. Management at IBM believed that it could not wait for business schools to do this, and in order to win the "war for talent" it must provide opportunities for continuous personal and professional employee development. Michelle Blieberg, the Chief Learning Officer at UBS, is also committed to the continuous development of global talent, particularly when the traditional graduate business school programs are insufficient. ${ }^{11}$

In August 2019, the Business Roundtable shocked many observers when they released a new "Statement on the Purpose of a Corporation." Signed by 181 CEOs, the statement committed their organizations to benefit "all" stakeholders

\footnotetext{
8 https://www/fus.edu/academics/graduate-programs/master-of-science-in-international-management

9 https://www.uvm.edu/business/simba_sustainable innovation_mba

10 For a skeptical view see Devinney (2009).

11 A conversation with Corinne Young, December 28, 2009, Philadelphia.
} 
- customers, employees, suppliers, and the communities they serve - and not just their shareholders. ${ }^{12}$ Are our business school graduates up to this challenge? We have argued in this essay that if we are to make progress in solving the problems affecting our global community, we need to focus increasingly on promoting and developing a set of values associated with global citizenship among our students. Corporate demand for managers who can deliver both societal contribution and competitive advantage is strongly pushing business schools to redefine and develop new pedagogies. Individual managers at the front line of their companies' operations must interpret information and make decisions that affect the well-being of fellow citizens, near and far. They must possess the tools and mindset essential to the job.

As large and difficult as this challenge may seem, the impact of individual educators can be significant and multiplicative. We have cited a few programs that are engaged in fostering sustainable management education. Many more are committed to such goals as evident in the enthusiastic response to the PRME efforts cited earlier. From such broad experimentation, new programs and initiatives will emerge, be tested for effectiveness, and disseminated to others. Experiential programs should make a significant contribution to these goals (Mirvis, 2008; Taras \& Gonzalez-Perez, 2014). "Really achieving the transformational change needed in management education will require reaching the hearts and minds of every single faculty member engaged in management research, teaching, and consulting" (Peters \& Gitsham, 2009). To effect transformational change will require university leaders to embody the skills and values needed to be a responsible global citizen and leader in the $21^{\text {st }}$ century. It is urgent that we rethink global management education. In the spirit of the World Café Community, we need to be wise together by cultivating collective intelligence through conversations that matter. ${ }^{13}$

\section{ABOUT THE AUTHORS}

José R. de la Torre (delatorrejoser@gmail.com) is cofounder and Chair of the EMBA Consortium for Global Business Innovation, professor at Bologna Business School, and Founding Dean of FIU's Chapman Graduate School of Business where he held the JK Batten Chair in Strategy (now Emeritus). He previously taught at UCLA, INSEAD, and Georgia State after earning his doctorate from Harvard Business School. His research deals with the management of multinational firms, trust in inter-corporate collaborations and the importance of global citizenship.

Corinne Young (cyoung@fus.edu) is the Director of Graduate Studies at Franklin University Switzerland. She received her Ph.D. from Tulane University. Her research and teaching centers on designing and implementing transformational learning experiences in graduate management education. She focuses her work on developing responsible leaders in a stakeholder society.

12 https://www.businessroundtable.org/business-roundtable-redefines-the-purpose-of-a-corporation-to-promote-an-economy-thatserves-all-americans

13 http://www.theworldcafe.com/ 


\begin{tabular}{|l|c|c|c|c|}
\hline & \multicolumn{4}{|c|}{ Focus of Activity or Target Area } \\
\hline $\begin{array}{l}\text { Nature of } \\
\text { Program }\end{array}$ & Sustainability & $\begin{array}{c}\text { Corporate } \\
\text { Responsibility and } \\
\text { Ethical Behavior }\end{array}$ & $\begin{array}{c}\text { Global and } \\
\text { Community } \\
\text { Development }\end{array}$ & $\begin{array}{c}\text { Social } \\
\text { Entrepreneurship }\end{array}$ \\
\hline Focused program & Only 2 & \multicolumn{3}{|c|}{ No activity reported } \\
\hline $\begin{array}{l}\text { Concentration or } \\
\text { specialization }\end{array}$ & & & & \\
\hline Joint degree & & & & \\
\hline $\begin{array}{l}\text { Core and/or } \\
\text { elective courses }\end{array}$ & & & & \\
\hline $\begin{array}{l}\text { Institutes and } \\
\text { Centers }\end{array}$ & & & & \\
\hline $\begin{array}{l}\text { Annual } \\
\text { conferences and } \\
\text { programs }\end{array}$ & & & & \\
\hline $\begin{array}{l}\text { Experiential } \\
\text { activities }\end{array}$ & & & & \\
\hline $\begin{array}{l}\text { Student clubs and } \\
\text { activities }\end{array}$
\end{tabular}

Note: These activities are self-reported by 114 and 145 (out of a sample of over 700) accredited business schools from around the world. The frequency reported in the table is based on whether a school reported at least one activity in that category for each target area. Thus, the figures under-represent the number of activities either because the schools failed to report it, or because they reported two or more activities in the same cell.

\begin{tabular}{|l|l|}
\hline & Activity with the highest frequency; over $50 \%$ of schools involved \\
\hline & Activity with high frequency; $33-50 \%$ of all schools report doing this \\
\hline & Activity with medium frequency: $20-33 \%$ of all schools reporting \\
\hline & Activity with low frequency: only $10-20 \%$ of schools involved \\
\hline & Activity with zero or less than 6 schools involved \\
\hline
\end{tabular}

\section{Table 1: Citizenship Teaching at Major Schools of Business}

Source: The Aspen Institute (The Aspen Institute, 2009, 2011).

This is an open-access article distributed under the terms of the Creative Commons Attribution 4.0 International License (CCBY-4.0). View this license's legal deed at http://creativecommons.org/licenses/by/4.0 and legal code at http://creativecommons.org/licenses/by/4.0/legalcode for more information. 


\section{REFERENCES}

AACSB. 2006. A World of Good: Business, Business Schools, and Peace. Tampa, FL: AACSB International.

Awaysheh, A., Heron, R. A., Perry, T., \& Wilson, J. I. 2020 . On the relation between corporate social responsibility and financial performance. Strategic Management Journal, 41(6): 965-987.

Bennis, W., \& O’Toole, J. 2005, May. How business schools lost their way. Harvard Business Review.

Bisoux, T. 2008. The socially responsible curriculum. BizEd, July/August, 22-30.

Bisoux, T. 2019. People, Planet, Profits-Peace. BizEd, September/October. https://bized.aacsb.edu/articles/ 2019/september/people-planets-profits-peace.

Brookings Institution. 2017. Measuring Global Citizenship Education: A Collection of Practices and Tools. https://www.brookings.edu/wp-content/upload s/2017/04/global_20170411_measuring-global-citizen ship.pdf.

Devinney, T. M. 2009. Is the socially responsible corporation a myth? The good, the bad, and the ugly of corporate social responsibility. Academy of Management Perspectives, 23(2): 44-56.

Ghoshal, S. 2005. Bad management theories are destroying good management practices. Academy of Management Learning and Education, 4(1): 71-91.

Haski-Leventhal, D., \& Pournader, M. 2017, February. Business students willing to sacrifice future salary for good corporate social responsibility. The Conversation. https://theconversation.com/businessstudents-willing-to-sacrifice-future-salary-for-goodcorporate-social-responsibility-study-73122.

Hulstrand, J. 2007. Educating for global business. International Educator, Fall: 36.

Janjuha-Jivraj, S. 2019. Creating Leaders by Building Global Citizens. https://www.forbes.com/sites/shahee najanjuhajivrajeurope/2019/11/19/creating-leaders-b y-building-global-citizens/.

Lilley, K., Barker, M., \& Harris, N. 2014. Educating global citizens in business schools. Journal of International Education in Business, 7(1): 72-84.
McGaw, N., \& Malinsky, E. 2020. Unlocking the Potential of Corporate Social Intrapreneurship: A Call to Scholars. The Aspen Institute. https://doi.org/ 10.2139/ssrn.3577762.

Mintzberg, H. 2004. Managers not MBAs: A Hard Look at the Soft Practice of Managing and Management Development. San Francisco: Berrett-Koehler.

Mirvis, P. 2008. Executive Development Through Consciousness-Raising Experiences. Academy of Management Learning \& Education, 7(2): 173-188.

Peters, K., \& Gitsham, M. 2009. Developing the global leader of tomorrow. EFMD Global Focus, 3(1): 58-61.

Pfeffer, J., \& Fong, C. T. 2002. The end of business schools? Less success than meets the eye. Academy of Management Learning \& Education, 1(September): 78-95.

Polman, K., \& Vasconcellos-Sharpe, S. 2017. Imaginal Cells: Visions of Transformation. Southall: Reboot the Future.

Porter, M. E., \& Kramer, M. R. 2006, December. Strategy \& society: The link between competitive advantage and corporate social responsibility. Harvard Business Review.

Raworth, K. 2017. Doughnut Economics: Seven Ways to Think Like a 21st Century Economist. White River Junction, VT: Chelsea Green Publishing.

Taras, V., \& Gonzalez-Perez, M. A. (Eds.). 2014. The Palgrave Handbook of Experiential Learning in International Business. Houndsmills: PalgraveMacmillan.

The Aspen Institute. 2009. Guide to Socially Responsible MBA Programs: 2008-2009. San Francisco: Berrett-Koehler Publishers, Inc.

The Aspen Institute. 2011. Guide to Socially Responsible MBA Programs: 2010-2011. San Francisco: Berrett-Koehler Publishers, Inc.

The Aspen Institute. 2020. A Crisis Curriculum? http s://www.aspeninstitute.org/blog-posts/a-crisis-curric ulum/.

United Nations. 2017. Impact: A Decade of Principles for Responsible Management Education. https://ww w.unprme.org/resource-docs/PRMEImpactReport.pdf. 